\title{
ANALISIS KUALITAS LAYANAN ATM DAN KEPUASAN PENGGUNA TERHADAP LOYALITAS PELANGGAN DENGAN PENDEKATAN STRUCTURAL EQUATION MODELLING
}

\author{
Sandra Aulia Zani ${ }^{1}$ \\ Deni Danial Kesa ${ }^{2}$ \\ 1 Laboratorium Akuntansi, Program Vokasi Universitas Indonesia,aulia_zanni@yahoo.com \\ 2 Laboratorium Keuangan dan Perbankan, Program Vokasi Universitas Indonesia, d.danial @ui.ac.id
}

Diterima : 1 Desember 2014

Layak Terbit : 3 Januari 2015

\section{Abstrak}

Penelitian ini disusun memiliki dengan mengkaji kembali pengaruh dari kualitas layanan yang diberikan melalui ATM pada salah satu Bank swasta terbesar di Indonesia terhadap loyalitas pelanggan yang terdiri dari kualitas informasi dan kualitas sistem terhadap loyalitas pelanggan ATM yang dimediasi oleh kepuasan pelanggan. Nilai t-hitung yang diperoleh dari Confirmatory Factor Analysis (CFA) untuk seluruh variabel menunjukkan bahwa seluruh butir pertanyaan yang termasuk dalam seluruh variabel signifikan secara statistik. Nilai koefisien Goodness of Fit memenuhi persyaratan kecocokan sebuah model, maka dapat disimpulkan bahwa secara umum, model yang diperoleh memiliki tingkat kecocokan yang baik. Kualitas layanan ATM mempunyai hubungan positif signifikan secara statistik dengan loyalitas pelanggan. Kepuasan terhadap kualitas kandungan informasi ATM dan kepuasan terhadap kinerja sistem ATM ternyata memang memiliki hubungan yang positif dengan kepuasan pelanggan. Variabel kepuasan dipengaruhi signifikan secara statistik oleh dua variabel bebas, yaitu Variabel Kualitas Informasi dan Kualitas Sistem. Kepuasan akan berdampak pada kepercayaan pelanggan terhadap penggunaan ATM sehingga akan muncul loyalitas pelanggan terhadap ATM pada Bank tersebut. Sesuai dengan hipotesa bahwa variabel kepuasan memberikan pengaruh yang signifikan secara statistik terhadap variabel loyalitas.

Kata Kunci : ATM, Confirmatory Factor Analysis,Kandungan informasi, kualitas system, loyalitas

\begin{abstract}
This research has been prepared for the purpose of reviewing the impact of the quality of services provided by ATM on one of the largest private bank in Indonesia on customer loyalty. In this case the quality of the service will be tested at one of the ATM Bank the largest private bank in Indonesia which consists of quality information and quality on customer loyalty ATM system on one of the largest private bank in Indonesia which is mediated by customer satisfaction. T-count value obtained from Confirmatory Factor Analysis (CFA) for all variables showed that all the questions are included in all variables statistically significant. The coefficient of Goodness of Fit meets the requirements of the suitability of a model, it can be concluded that in general, the model obtained has a good level of compatibility. ATM service quality has a statistically significant positive relationship with customer loyalty. Satisfaction with the quality of the information content of ATM and satisfaction with the performance of the ATM system did in fact have a positive relationship with customer satisfaction. Variable satisfaction statistically significant influenced by two independent variables, namely variable quality and Quality Information System. Satisfaction will impact on the confidence of customers to use ATMs that will appear on the ATM customer loyalty to the Bank. In accordance with the hypothesis that the satisfaction variables provide a statistically significant effect on the variable loyalty.
\end{abstract}

Key words : ATM, Confirmatory Factor Analysis, Kandungan informasi, kualitas system, loyalitas

\section{PENDAHULUAN}

\section{Latar Belakang}

Teknologi yang berkembang dalam industri jasa keuangan melalui berbagai inovasi.
Volume perdagangan dan aktivitas keuangan lainnya meningkat secara geometris difasilitasi oleh teknologi tersebut. Pengaruh teknologi terhadap inovasi produk dalam 
dunia perbankanpun sangat beragam. Dalam proses inovasi bank harus memutuskan produk apa yang akan mereka jual, apakah mereka berharap membuat produk itu sendiri, bagaimana mereka mengirimnya kepada pelanggan (Raihan et al, 2001). Inovasi merupakan seni untuk mengatasi kendala terhadap kemajuan. Hal tersebut timbul pada saat terdapat perubahan produk atau jasa, dan adanya produk atau jasa baru yang diperkenalkan kepada masyarakat, atau pada saat proses baru atau dirubah digunakan dalam situasi komersial. Tidak ada organisasi dapat bertahan dengan produk yang telah ada apabila terdapat pesaing, tidak terkecuali pada bank (Shahid, 2004).

Automated Teller Machine (ATM) merupakan salah satu inovasi yang secara mekanis dapat melakukan penarikan tunai, mentransfer dana antar rekening, membayar tagihan, dan lain sebagainya. Disamping itu, kehadiran kemajuan teknologi seperti ATM mempunyai dampak positif yaitu dapat memberikan informasi kepada pelanggan mengenai jumlah saldo dalam rekening, jumlah tagihan yang harus dibayarkan, jumlah dana yang ditransfer dari rekening lain tanpa harus mengunjungi teller atau datang ke Bank langsung pada waktu yang telah ditentukan. Oleh karena itu, manusia dewasa ini semakin dimanjakan dengan kemudahan mengakses informasi dengan cepat melalui bantuan ATM. Mereka sudah tidak perlu repot dengan mengunjungi bank. Pengguna ATM dari hari ke hari terus meningkat. Litan (1999) mengemukakan pengenalan dan pengunaan ATM yang terus meningkat sebagai suatu bentuk revolusi dalam sektor perbankan. ATM tidak hanya muncul di daerah perkotaan saja tetapi sudah merambah daerah pedesaan. Dari fakta tersebut terlihat bahwa keberadaan ATM saat ini sangat diperlukan bagi setiap manusia.

Semakin banyaknya ATM yang tersebar di berbagai daerah juga akan mendorong semakin meningkatnya pengguna ATM. Seseorang tidak harus membawa uang kas dalam jumlah yang besar untuk mengunjungi suatu daerah.

Kualitas layanan ATM sangat mempengaruhi tingkat kepuasan dari pengguna jasa tersebut. Apabila kualitas jasa yang diberikan melalui ATM membuat pelanggan merasa puas dengan layanan tersebut, maka tingkat kepuasan yang semakin tinggi akan mendorong pengguna untuk setia terhadap penggunaan ATM tersebut, yaitu dengan terus menggunakan jasa yang diberikan dari ATM.

Berbagai artikel telah dikeluarkan berkaitan dengan electronic banking, computerization, innovation dalam sektor perbankan. Walaupun banyak bank yang mengeluarkan kartu ATM memberikan brosur untuk membuat pengguna memahami ATM, dan bagaimana menggunakan jasa, biaya servis, dan sebagainya, namun mereka jarang mempunyai informasi berkaitan dengan tingkat kepuasan pelanggan terkait dengan aspek penggunaan ATM.

\section{2 Automatic Teller Machine (ATM)}

Automatic Teller Machine atau Anjungan Tunai Mandiri (ATM) merupakan suatu alat 
yang memberikan pelanggan bank untuk menarik tunai atau memeriksa rekening kapan saja tanpa bantuan teller.James J. Mcandrews (2003) membahas berbagai manfaat dari ATM dikarenakan ATM semakin berkembang dan terkenal. Professor Norman Penney dalam Islam (2004) menyatakan bahwa perkembangan jasa ATM terjadi karena tiga alasan. Pertama, institusi keuangan berharap untuk meningkatkan posisi bersaing mereka dengan menarik pelanggan dan meningkatkan pendapatan dengan meningkatkan pinjaman, menciptakan saldo yang lebih tinggi, dan meningkatkan jasa keuangan. Kedua, ATM dirancang untuk melakukan banyak tugas yang sama seperti teller pada biaya yang lebih rendah dan mudah. Ketiga, institusi keuangan membuat keputusan ATM berdasarkan pertimbangan pemasaran.

\subsection{Kualitas Layanan ATM dan Loyalitas Pelanggan}

Caruana (2002) yang menunjukkan bahwa loyalitas pelanggan dipengaruhi oleh kualitas layanan dan dimediasi oleh kepuasan pelanggan. Berdasarkan hal tersebut, maka hipotesis yang terbentuk adalah:

H1: Kualitas layanan ATM mempunyai hubungan positif dengan loyalitas pelanggan.

\subsection{Kualitas Layanan ATM dan Kepuasan Pengguna ATM}

McKinney et al. (2002) menyatakan bahwa kepuasan pengguna akhir merupakan hal penting dalam riset sistem informasi karena mempertimbangkan faktor yang signifikan yang mempengaruhi kesuksesan sistem informasi dan penggunaannya. DeLone dan McLean (1992 dalam Livari, 2005) memisahkan aspek informasi dan sistem sebagai faktor yang mempengaruhi kepuasan. Sedangkan, untuk mengukur kualitas informasi adalah dari keakuratan, presisi, kemutakhiran atau up to date, tepat waktu, dapat dipercaya kelengkapan, format, dan relevansi (Livari, 2005).

Beberapa penelitian menemukan bahwa kepuasan pengguna berkaitan dengan kepuasan terhadap sistem (Doll dan Torkzadeh, 1988 dalam Doll, Xia, dan Torkzadeh, 1994) atau fungsi sistem informasi (Bailey dan Pearson, 1983; Baroudi dan Orlikowski, 1988 dalam Livari, 2005). Pengukuran kepuasan pelanggan ATM dapat dilihat dari dua hal yaitu kepuasan terhadap kualitas kandungan informasi ATM dan kepuasan terhadap kinerja sistem ATM.

Berdasarkan pembahasan di atas, maka hipotesis yang diajukan dalam penelitian ini adalah:

H2: Kualitas layanan ATM berhubungan positif dengan kepuasan pelanggan.

\subsection{Kepuasan Pengguna ATM dan Loyalitas Pelanggan}

Kepuasan akan berdampak pada kepercayaan pelanggan terhadap penggunaan ATM (Livari, 2005). Studi sebelumnya mengenai royalti dari penelitian Jones dan Sasser (1995), Hallowell (1996); Mittal dan Lassar (1998); Oliver (1999); Kandampully dan Suhartanto (2000); Bowen dan Chen (2001) mendokumentasikan bahwa outcome dari 
kepuasan adalah loyalitas. Oleh karena itu, hipotesis yang diajukan adalah:

H3: Kepuasan pelanggan berhubungan positif dengan loyalitas pelanggan.

Oleh karena itu penelitian ini mencoba menganalisa kualitas layanan ATM mempengaruhi loyalitas pelanggan yang dimediasi oleh tingkat kepuasan pengguna. Penelitian ini menggunakan sampel pengguna ATM pada salah satu Bank swasta terbesar di Indonesia. Berdasarkan latar belakang masalah yang ada maka permasalahan penelitian yang diajukan antara lain: apakah kualitas layanan ATM pada salah satu Bank swasta terbesar di Indonesia mempengaruhi loyalitas pelanggan melalui kepuasan pengguna ATM tersebut?

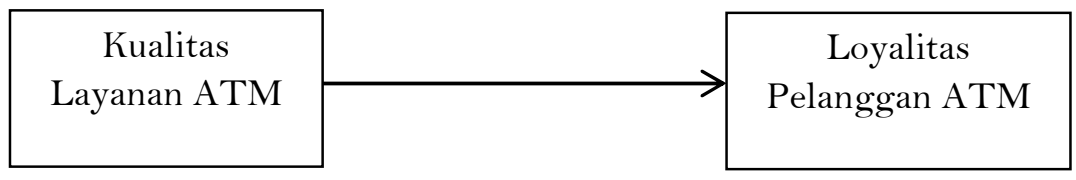

Gambar 1. Basic Model model pengembangan teoritis kualitas layanan, kepuasan pengguna, dan loyalitas pelanggan ATM

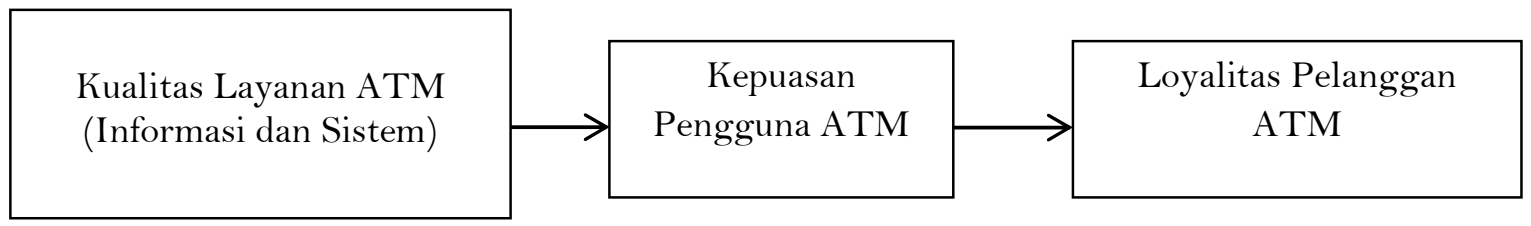

Gambar 2. Redefined Model model pengembangan teoritis kualitas layanan, kepuasan pengguna, dan loyalitas pelanggan ATM

\section{METODE PENELITIAN}

Unit analisis penelitian ini adalah individu. Populasi adalah pengguna ATM pada salah satu Bank swasta terbesar di Indonesia yang ada di Jakarta. Pada penelitian ini diambil 20 responden yang kemudian oleh peneliti dilakukan bootstraps menjadi 100 responden. Responden merupakan karyawan/wati dari beberapa perusahaan yang ada di Jakarta. Mereka akan diminta untuk menjawab kuesioner yang dilakukan dengan cara langsung diisi dan ditunggu oleh peneliti sehingga kuesioner tidak dibawa pulang oleh responden. Hal ini dilakukan agar semua kuisioner yang diberikan dapat kembali seluruhnya. Dalam melakukan pengujian dalam penelitian ini menggunakan software LISREL 8.8 versi mahasiswa (Student Version). 
diberikan (Kinf) dan kualitas sistem (Ksis).

Kualitas informasi adalah kualitas dari kandungan informasi yang disediakan oleh ATM (seperti informasi saldo rekening, jumlah tagihan listrik, telepon, kartu kredit) dan kualitas sistem adalah kualitas dari sistem layanan ATM (seperti tarik tunai, transfer, perubahan PIN, pembayaran tagihan dan fasilitas lainnya).

Pengukuran kualitas informasi menggunakan instrumen dari McKinney et al. (2002) yang terbagi menjadi 4 (empat) pengukuran, yaitu: 1) relevansi (4 konstruk), 2) mudah dimengerti memiliki 4 pernyataan, 3) dapat dipercaya memiliki 4 pernyataan, 4) adequacy (4 konstruk). Kualitas sistem diukur dengan akses yang diwakilkan dengan 4 pernyataan, yaitu: 1) usability dengan indikator 5 pernyataan, 2) hyperlink (2 konstruk), 3) navigasi dengan 3 konstruk, dan 4) interaktif (5 konstruk). Skala yang digunakan adalah 5 skala likert dengan o (sangat tidak penting) sampai 5 (sangat penting). Variabel endogen ada 2 (dua) yaitu 1) kepuasan pelanggan ATM dan 2) loyalitas pelanggan ATM. sistem dari ATM. Pengukuran kepuasan pelanggan menggunakan instrumen dari Islam et al. (2004) yaitu 1) kepuasan terhadap kualitas informasi (Kepinf) diukur dengan 5 indikator dan 2) kepuasan terhadap kualitas sistem (Kepsis) diukur dengan 2 indikator. Masing-masing menggunakan pernyataan diukur dengan skala likert o (sangat tidak setuju) sampai 5 (sangat setuju). Dalam penelitian ini variabel kepuasan pelanggan merupakan variabel mediasi (intervening variable) yang memediasi hubungan antara kualitas ATM dengan loyalitas pelanggan. Sedangkan, untuk variabel loyalitas pelanggan merupakan kesetiaan pelanggan terhadap produk ATM. Pengukuran loyalitas pelanggan menggunakan instrumen dari Cruana (2002) dengan 4 indikator pernyataan.

\section{HASIL ANALISIS DAN PEMBAHASAN}

Langkah analisis data diawali dengan melakukan Analisis Validitas dan Reliabilitas.

Tabel 1. Profil responden dalan penelitian

\begin{tabular}{|l|l|}
\hline Usia & Rata-rata 29 tahun \\
\hline Jenis Kelamin & Laki-laki 11 orang, Wanita 9 orang \\
\hline Status perkawinan & Menikah 12 orang, Belum Menikah 8 orang \\
\hline Pendidikan & S2 4 orang, S1 14 orang dan D3 2 orang \\
\hline Status Kepegawaian & Tetap 18 orang, honorer 2 orang \\
\hline Lama Bekerja & Rata-rata 6 tahun \\
\hline
\end{tabular}

Sumber : Penelitian, data primer diolah,2015

Kepuasan pelanggan adalah kepuasan pelanggan terhadap kualitas informasi dan
Langkah selanjutnya adalah melakukan

Analisis Confirmatory Factor Analysis dan 
diakhiri dengan Analisis Structural Equation

Modeling (SEM). Pengujian Validitas dan

Reliabilitas.

Hasil pengujian validitas dan reliabilitas yang dilakukan atas variabel-variabel tersebut adalah sebagai berikut:
Tabel 3 adalah hasil output uji validitas dan reliabilitas untuk Dimensi Dimengerti. Seluruh pertanyaan yang digunakan dalam Dimensi ini memiliki nilai validitas yang lebih besar dari 0,300 dan dinyatakan valid. Sedangkan nilai reliabilitas dari Dimensi ini sebesar 0,922. Nilai ini lebih besar dari 0,700 yang menjadi batasan minimum reliabilitas.

Tabel 2 Dimensi Relevansi

Item-Total Statistics

\begin{tabular}{|l|r|r|r|r|}
\hline & $\begin{array}{c}\text { Scale Mean if } \\
\text { Item Deleted }\end{array}$ & $\begin{array}{c}\text { Scale } \\
\text { Variance if } \\
\text { Item Deleted }\end{array}$ & $\begin{array}{c}\text { Corrected } \\
\text { Item-Total } \\
\text { Correlation }\end{array}$ & $\begin{array}{c}\text { Cronbach's } \\
\text { Alpha if Item } \\
\text { Deleted }\end{array}$ \\
\hline REL_1 & 14.3500 & 1.846 & .730 & .841 \\
REL_2 & 14.3500 & 1.644 & .661 & .853 \\
REL_3 & 14.4500 & 1.361 & .823 & .785 \\
REL_4 & 14.4500 & 1.462 & .717 & .834 \\
\hline
\end{tabular}

Reliability Statistics

\begin{tabular}{|r|r|}
\hline $\begin{array}{c}\text { Cronbach's } \\
\text { Alpha }\end{array}$ & N of Items \\
\hline .867 & 4 \\
\hline
\end{tabular}

Sumber : Data Peneliti diolah

Tabel 3 Dimensi Dimengerti

Item-Total Statistics

\begin{tabular}{|c|c|c|c|c|c|c|}
\hline & \multirow[b]{2}{*}{$\begin{array}{l}\text { Scale Mean if } \\
\text { Item Deleted }\end{array}$} & \multirow{2}{*}{$\begin{array}{c}\text { Scale } \\
\text { Variance if } \\
\text { Item Deleted }\end{array}$} & \multirow{2}{*}{$\begin{array}{l}\text { Corrected } \\
\text { Item-Total } \\
\text { Correlation }\end{array}$} & \multirow{2}{*}{$\begin{array}{l}\text { Cronbach's } \\
\text { Alpha if Item } \\
\text { Deleted }\end{array}$} & \multicolumn{2}{|c|}{ Reliability Statistics } \\
\hline & & & & & $\begin{array}{l}\text { Cronbach's } \\
\text { Alpha }\end{array}$ & $\mathrm{N}$ of ltems \\
\hline$\overline{\text { DIM_1 }}$ & 13.1000 & 3.626 & 855 & .886 & $\begin{array}{r}\text { Mupna } \\
.922\end{array}$ & 4 \\
\hline DIM_2 & 13.2000 & 4.303 & .778 & .915 & & \\
\hline DIM_3 & 13.4000 & 3.374 & .897 & 871 & & \\
\hline DIM_4 & 13.4000 & 3.879 & 772 & 914 & & \\
\hline
\end{tabular}

Sumber : Data Peneliti diolah

Tabel 2 di atas adalah hasil dari uji validitas dan reliabilitas untuk Dimensi Relevansi. Seluruh pertanyaan yang digunakan dalam dimensi ini memiliki nilai validitas yang lebih besar dari 0,300 dan dinyatakan valid. Sedangkan nilai reliabilitas dari dimensi ini sebesar 0,867. Nilai ini lebih besar dari 0,700 yang menjadi batasan minimum reliabilitas. Berdasarkan hasil di atas, disimpulkan bahwa Dimensi Relevansi telah memenuhi persyaratan Validitas dan Reliabilitas.
Berdasarkan hasil di atas, disimpulkan bahwa Dimensi Dimengerti telah memenuhi persyaratan Validitas dan Reliabilitas.

Sedangkan dimensi untuk bisa dipercaya. Seluruh pertanyaan yang digunakan dalam Dimensi ini memiliki nilai validitas yang lebih besar dari 0,300 dan dinyatakan valid. Sedangkan nilai reliabilitas dari Dimensi ini sebesar 0,765. Nilai ini lebih besar dari 0,700 yang menjadi batasan minimum reliabilitas. Berdasarkan hasil di atas,dapat disimpulkan 
bahwa Dimensi Dipercaya telah memenuhi persyaratan Validitas dan Reliabilitas.
Dimensi Usability telah memenuhi persyaratan Validitas dan Reliabilitas.

Tabel 4. Dimensi Adequacy

Item-Total Statistics

\begin{tabular}{|l|r|r|r|r|}
\hline & $\begin{array}{c}\text { Scale Mean if } \\
\text { Item Deleted }\end{array}$ & $\begin{array}{c}\text { Scale } \\
\text { Variance if } \\
\text { ltem Deleted }\end{array}$ & $\begin{array}{c}\text { Corrected } \\
\text { Item-Total } \\
\text { Correlation }\end{array}$ & $\begin{array}{c}\text { Cronbach's } \\
\text { Alpha if Item } \\
\text { Deleted }\end{array}$ \\
\hline DIP_1 & 11.0000 & 3.636 & .506 & .742 \\
DIP_2 & 11.5000 & 3.889 & .521 & .732 \\
DIP_3 & 11.1000 & 3.182 & .655 & .657 \\
DIP_4 & 10.8000 & 3.556 & .585 & .699 \\
\hline
\end{tabular}

Reliability Statistics

\begin{tabular}{|r|r|}
\hline $\begin{array}{c}\text { Cronbach's } \\
\text { Alpha }\end{array}$ & N of Items \\
\hline 833 & 4 \\
\hline
\end{tabular}

Sumber : Data Peneliti diolah

Tabel di atas merupakan output uji validitas dan reliabilitas untuk Dimensi Adequacy. Seluruh pertanyaan yang digunakan dalam Dimensi ini memiliki nilai validitas yang lebih besar dari 0,300 dan dinyatakan valid.
Sedangkan nilai reliabilitas dari Dimensi ini sebesar 0,833. Nilai ini lebih besar dari 0,700 yang menjadi batasan minimum reliabilitas. Berdasarkan hasil di atas, disimpulkan bahwa Dimensi Adequacy telah memenuhi persyaratan Validitas dan Reliabilitas.

Tabel 5 Dimensi Usabillity

Item-Total Statistics

\begin{tabular}{|l|r|r|r|r|}
\hline & $\begin{array}{c}\text { Scale Mean if } \\
\text { tem Deleted }\end{array}$ & $\begin{array}{c}\text { Scale } \\
\text { Variance if } \\
\text { item Deleted }\end{array}$ & $\begin{array}{c}\text { Corrected } \\
\text { item-Total } \\
\text { Correlation }\end{array}$ & $\begin{array}{c}\text { Cronbach's } \\
\text { Alpha if item } \\
\text { Deleted }\end{array}$ \\
\hline ADE_1 & 13.6000 & 3.071 & 652 & .797 \\
ADE_2 & 13.3000 & 3.545 & .805 & 750 \\
ADE_3 & 13.3500 & 4.068 & .650 & 816 \\
ADE_4 & 13.7500 & 2.513 & .715 & .790 \\
\hline
\end{tabular}

Sumber : Data Peneliti diolah

Tabel di atas merupakan output uji validitas dan reliabilitas untuk Dimensi Usability. Seluruh pertanyaan yang digunakan dalam Dimensi ini memiliki nilai validitas yang lebih besar dari 0,300 dan dinyatakan valid. Sedangkan nilai reliabilitas dari Dimensi ini sebesar 0,714. Nilai ini lebih besar dari 0,700 yang menjadi batasan minimum reliabilitas Berdasarkan hasil di atas, disimpulkan bahwa
Reliability Statistics

\begin{tabular}{|r|r|}
\hline $\begin{array}{c}\text { Cronbach's } \\
\text { Alpha }\end{array}$ & N of Items \\
\hline 765 & 4 \\
\hline
\end{tabular}


reliabilitas. Berdasarkan hasil di atas, disimpulkan bahwa Dimensi Hyperlink telah memenuhi persyaratan Validitas dan Reliabilitas yang digunakan dalam Dimensi ini memiliki nilai validitas yang lebih besar dari 0,300 dan dinyatakan valid.

Tabel 6 Dimensi hyperlink

Item-Total Statistics

\begin{tabular}{|l|r|r|r|r|}
\hline & $\begin{array}{c}\text { Scale Mean if } \\
\text { Item Deleted }\end{array}$ & $\begin{array}{c}\text { Scale } \\
\text { Variance if } \\
\text { Item Deleted }\end{array}$ & $\begin{array}{c}\text { Corrected } \\
\text { Item-Total } \\
\text { Correlation }\end{array}$ & $\begin{array}{c}\text { Cronbach's } \\
\text { Alpha if Item } \\
\text { Deleted }\end{array}$ \\
\hline HYP_1 & 3.9500 & .452 & .586 & \\
HYP_2 & 4.4000 & .44 & 586 & \\
\hline
\end{tabular}

a. The value is negative due to a negative average covariance among items. This violates reliability model assumptions. You may want to check item codings.

Sumber : Data Peneliti diolah

Tabel 7 Dimensi Navigasi

Item-Total Statistics

\begin{tabular}{|l|r|r|r|r|}
\hline & $\begin{array}{c}\text { Scale Mean if } \\
\text { Item Deleted }\end{array}$ & $\begin{array}{c}\text { Scale } \\
\text { Variance if } \\
\text { Item Deleted }\end{array}$ & $\begin{array}{c}\text { Corrected } \\
\text { Item-Total } \\
\text { Correlation }\end{array}$ & $\begin{array}{c}\text { Cronbach's } \\
\text { Alpha if Item } \\
\text { Deleted }\end{array}$ \\
\hline USA_1 & 18.5000 & 2.515 & .636 & .618 \\
USA_2 & 16.8500 & 4.735 & 520 & .678 \\
USA_3 & 17.1000 & 4.354 & .445 & 679 \\
USA_4 & 17.2500 & 3.725 & 462 & 674 \\
USA_5 & 16.9000 & 4.576 & 559 & 664 \\
\hline
\end{tabular}

Sumber : Data Peneliti diolah

Tabel di atas merupakan output uji validitas dan reliabilitas untuk Dimensi Navigasi. Seluruh pertanyaan yang digunakan dalam Dimensi ini memiliki nilai validitas yang lebih besar dari 0,300 dan dinyatakan valid. Sedangkan nilai reliabilitas dari Dimensi ini sebesar 0,870. Nilai ini lebih besar dari 0,700 yang menjadi batasan minimum reliabilitas. Berdasarkan hasil di atas, disimpulkan bahwa Dimensi Navigasi telah memenuhi persyaratan Validitas dan Reliabilitas.

Sedangkan output uji validitas dan reliabilitas untuk Dimensi Interaktif. Seluruh pertanyaan

\section{Reliability Statistics}

\begin{tabular}{|r|r|}
\hline $\begin{array}{c}\text { Cronbach's } \\
\text { Alpha }\end{array}$ & N of ltems \\
\hline .739 & 2 \\
\hline
\end{tabular}

Reliability Statistics

\begin{tabular}{|r|r|}
\hline $\begin{array}{c}\text { Cronbach's } \\
\text { Alpha }\end{array}$ & N of ltems \\
\hline .714 & 5 \\
\hline
\end{tabular}


minimum reliabilitas. Berdasarkan hasil di atas, disimpulkan bahwa Dimensi Kepuasan Informasi telah memenuhi persyaratan Validitas dan Reliabilitas. validitas yang lebih besar dari 0,300 dan dinyatakan valid. Sedangkan nilai reliabilitas dari Dimensi ini sebesar 0,869.

Tabel 7 Dimensi Kepuasan Informasi

Item-Total Statistics

\begin{tabular}{|l|r|r|r|r|}
\hline & $\begin{array}{c}\text { Scale Mean if } \\
\text { Item Deleted }\end{array}$ & $\begin{array}{c}\text { Scale } \\
\text { Variance if } \\
\text { item Deleted }\end{array}$ & $\begin{array}{c}\text { Corrected } \\
\text { Item-Total } \\
\text { Correlation }\end{array}$ & $\begin{array}{c}\text { Cronbach's } \\
\text { Alpha if Item } \\
\text { Deleted }\end{array}$ \\
\hline KEP-I_1 & 16.1300 & 10.720 & .701 & .788 \\
KEP-1_2 & 16.6600 & 10.550 & .617 & .804 \\
KEP-1_3 & 16.8800 & 8.248 & .650 & .813 \\
KEP-1_4 & 15.9800 & 9.070 & .657 & .796 \\
KEP-1_5 & 15.7900 & 11.824 & .783 & .799 \\
\hline
\end{tabular}

Sumber : Data Peneliti diolah
Reliability Statistics

\begin{tabular}{|r|r|}
\hline $\begin{array}{c}\text { Cronbach's } \\
\text { Alpha }\end{array}$ & N of Items \\
\hline .833 & 5 \\
\hline
\end{tabular}

Tabel 8 Dimensi Kepuasan Sistem

\begin{tabular}{|l|r|r|r|r|}
\multicolumn{1}{|c|}{ Item-Total Statistics } \\
\hline & $\begin{array}{c}\text { Scale Mean if } \\
\text { Item Deleted }\end{array}$ & $\begin{array}{c}\text { Scale } \\
\text { Variance if } \\
\text { Item Deleted }\end{array}$ & $\begin{array}{c}\text { Corrected } \\
\text { Item-Total } \\
\text { Correlation }\end{array}$ & $\begin{array}{c}\text { Cronbach's } \\
\text { Alpha if Item } \\
\text { Deleted }\end{array}$ \\
\hline KEP-S_1 & 4.5900 & .487 & .782 & \\
KEP-S_2 & 4.3600 & .718 & .782 & \\
\hline
\end{tabular}

Reliability Statistics

\begin{tabular}{|r|r|}
\hline $\begin{array}{c}\text { Cronbact's } \\
\text { Apha }\end{array}$ & Nof ttems \\
\hline 869 & 2 \\
\hline
\end{tabular}

a. The value is negative due to a negative average covariance among items. This violates reliability model assumptions. You may want to check item codings.

Sumber : Data Peneliti diolah

Tabel 9 Dimensi Loyalitas

Item-Total Statistics

\begin{tabular}{|l|r|r|r|r|}
\hline & $\begin{array}{c}\text { Scale Mean if } \\
\text { Item Deleted }\end{array}$ & $\begin{array}{c}\text { Scale } \\
\text { Variance if } \\
\text { Item Deleted }\end{array}$ & $\begin{array}{c}\text { Corrected } \\
\text { Item-Total } \\
\text { Correlation }\end{array}$ & $\begin{array}{c}\text { Cronbach's } \\
\text { Alpha if Item } \\
\text { Deleted }\end{array}$ \\
\hline LOY1 & 9.8700 & 8.296 & .855 & .863 \\
LOY2 & 9.4200 & 8.307 & .801 & .875 \\
LOY3 & 9.6500 & 6.674 & .778 & .879 \\
LOY4 & 9.9700 & 6.231 & 805 & .874 \\
\hline
\end{tabular}

Sumber : Data Peneliti diolah

Tabel Nomor 8 merupakan output uji validitas dan reliabilitas untuk Dimensi Kepuasan Sistem. Seluruh pertanyaan yang digunakan dalam Dimensi ini memiliki nilai
Reliability Statistics

\begin{tabular}{|r|r|}
\hline $\begin{array}{c}\text { Cronbach's } \\
\text { Alpha }\end{array}$ & N of ltems \\
\hline 901 & 4 \\
\hline
\end{tabular}


Kepuasan Sistem telah memenuhi persyaratan

Validitas dan Reliabilitas.

Tabel 9 di atas merupakan output uji validitas dan reliabilitas untuk Dimensi Loyalitas.
Seluruh pertanyaan yang digunakan dalam Dimensi ini memiliki nilai validitas yang lebih besar dari 0,300 dan dinyatakan valid.

Sedangkan nilai reliabilitas dari Dimensi ini sebesar 0,901. Nilai ini lebih besar dari 0,700 yang menjadi batasan minimum reliabilitas.

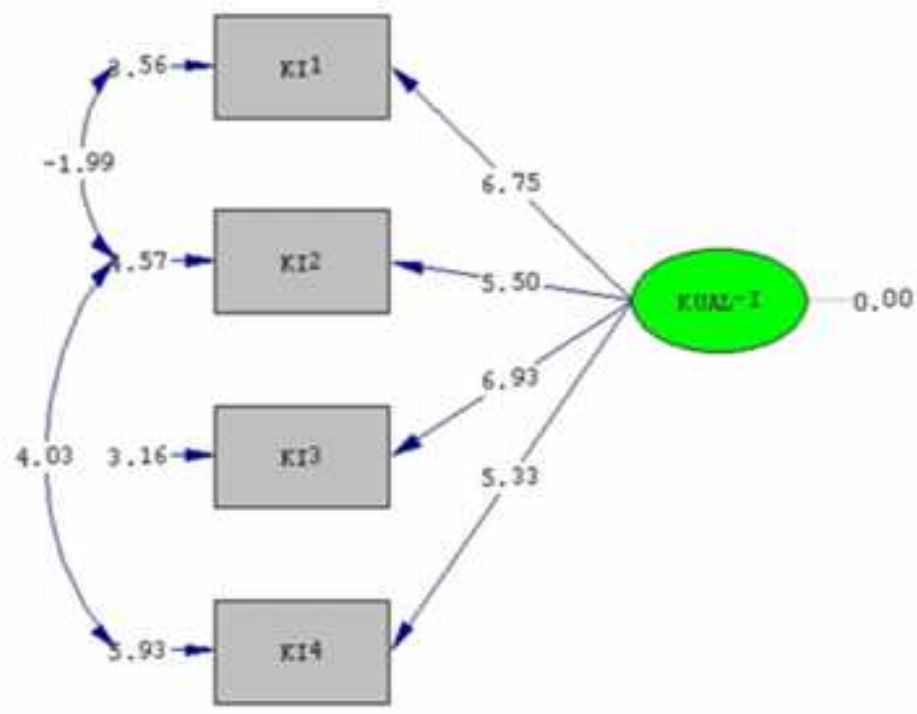

Chi-Square $=0.00, d f=0, \quad p-v a l u e=1.00000, \quad$ RMSEA $=0.000$

Gambar 3. Variabel Kualitas Informasi (Kinf) CR data diolah, 2015

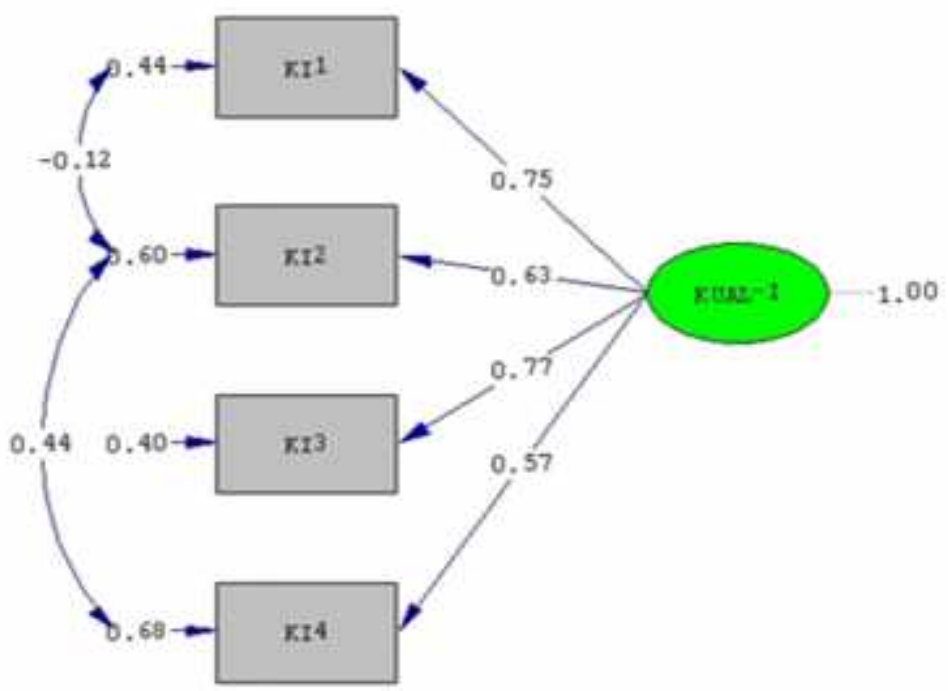

Chi-Square $=0.00, d f=0, \quad$-value $=1.00000, \quad$ RMSEA $=0.000$

Gambar 4. Variabel Kualitas Informasi (KS) VE data diolah, 2015 


\section{CONFIRMATORY FACTOR ANALYSIS}

Gambar 3 merupakan nilai - nilai t-hitung yang diperoleh dari analisis CFA untuk Variabel Kualitas Informasi. Hasil yang diperoleh menunjukkan bahwa seluruh butir pertanyaan yang termasuk dalam variabel Kualitas Informasi signifikan secara statistik. Ini ditunjukkan oleh nilai t-hitung yang diperoleh, di mana seluruh nilai t-hitung yang diperoleh lebih besar dari 1,96.
Sementara itu, gambar di atas menunjukkan nilai loading dari masing - masing indikator untuk Variabel Kualitas Informasi. Dengan nilai tersebut dihitung Construct Reliability (CR) dan Variance Extracted (VE).

Nilai CR yang diperoleh sebesar $77.70 \%$ telah memenuhi kriteria, yaitu di atas 0,700 (70\%);

Tabel 10 nilai Construct Reliability (CR) dan Variance Extracted

\begin{tabular}{|l|l|l|}
\hline Indikator & Loading & Error \\
\hline KI_1 & 0.75 & 0.44 \\
\hline KI_2 & 0.63 & 0.60 \\
\hline KI_3 & 0.77 & 0.41 \\
\hline KI_4 & 0.57 & 0.68 \\
\hline CR & $77.70 \%$ & \\
\hline VE & $46.93 \%$ & \\
\hline
\end{tabular}

Sumber : Data Peneliti diolah

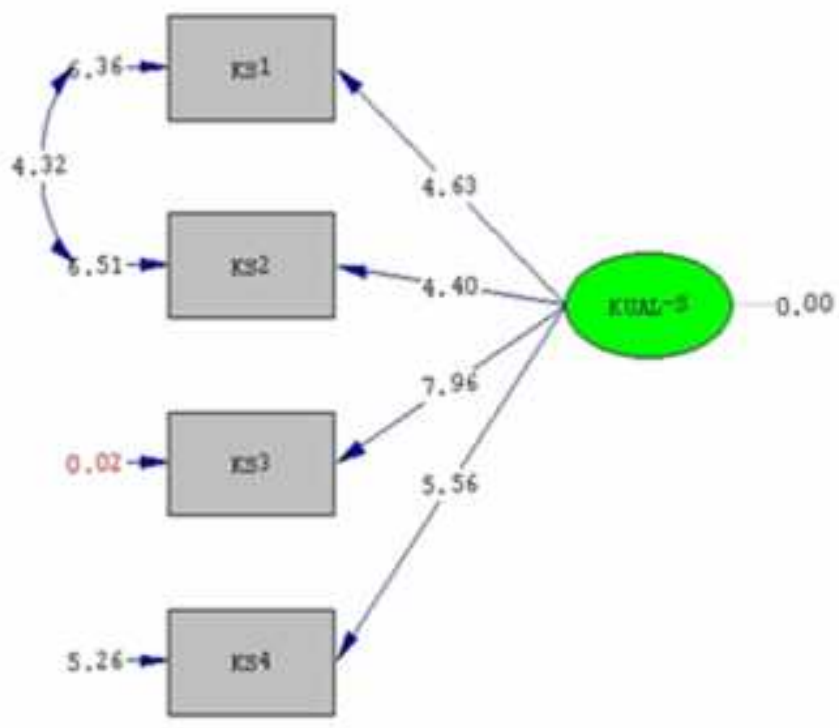

Chi-Square $=0.41$, df $=1, P$-value $=0.52286$, RMSEA $=0.000$

Gambar 4. Variabel Kualitas Sistem (Ksis CR data diolah, 2015 
sementara nilai VE sebesar $46.93 \%$ masih sedikit dibawah batasan ideal, yaitu 0,500 (50\%); namun, data yang diperoleh masih dapat dinyatakan sudah cukup baik. ditunjukkan oleh nilai t-hitung yang diperoleh, di mana seluruh nilai t-hitung yang diperoleh lebih besar dari 1,96.

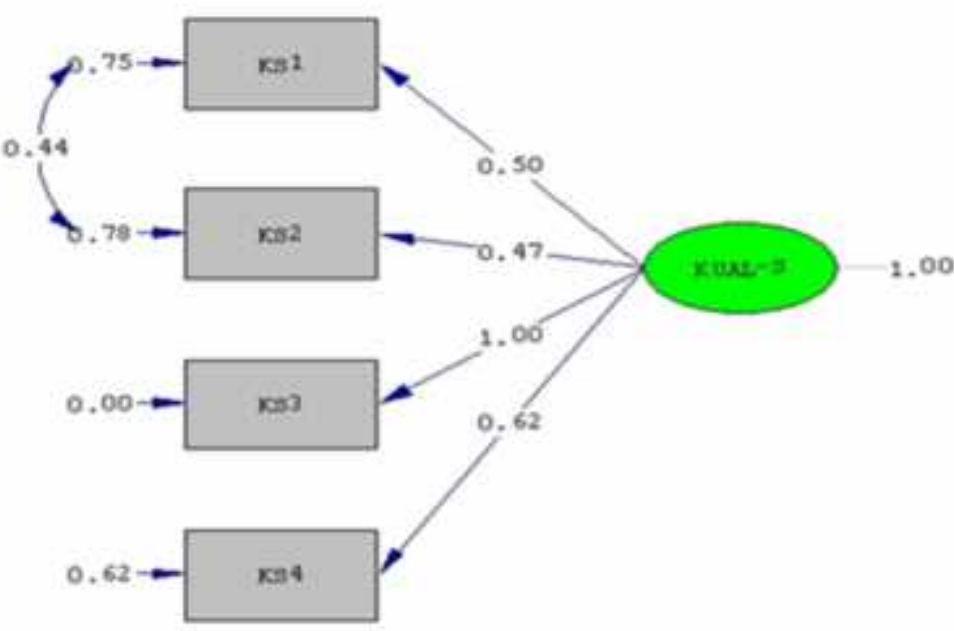

Chi-Squarem0.41, df=1, P-value=0.52286, RMSEA=0.000

Gambar 5. Variabel Kualitas Sistem (Ksis VE, data diolah, 2015

Tabel 11 nilai Construct Reliability (CR) dan Variance Extracted

\begin{tabular}{|c|c|c|}
\hline Indikator & Loading & Error \\
\hline KS_1 & 0.50 & 0.75 \\
\hline KS_2 & 0.47 & 0.78 \\
\hline KS_3 & 1.00 & 0.00 \\
\hline KS_4 & 0.62 & 0.62 \\
\hline CR & \multicolumn{2}{|c|}{$75.77 \%$} \\
\hline VE & \multicolumn{2}{|c|}{$46.38 \%$} \\
\hline
\end{tabular}

Sumber : Data Peneliti diolah

ara itu, tabel di atas menunjukkan nilai

Gambar di atas merupakan nilai - nilai thitung yang diperoleh dari analisis CFA untuk Variabel Kualitas Sistem. Hasil yang diperoleh menunjukkan bahwa seluruh butir pertanyaan yang termasuk dalam variabel Kualitas Sistem signifikans secara statistik. Ini loading dari masing - masing indikator untuk Variabel Kualitas Sistem. Dengan nilai tersebut dihitung Construct Reliability $(\mathrm{CR})$ dan Variance Extracted (VE) . Nilai CR yang diperoleh sebesar $75.77 \%$ telah memenuhi kriteria, yaitu di atas 0,700 (70\%); 
Sementara nilai VE sebesar 46,38\% masih sedikit dibawah batasan ideal, yaitu 0,500 (50\%); namun, data yang diperoleh masih dapat dinyatakan sudah cukup baik.
Gambar di atas merupakan nilai - nilai thitung yang diperoleh dari analisis CFA untuk Variabel Loyalitas.

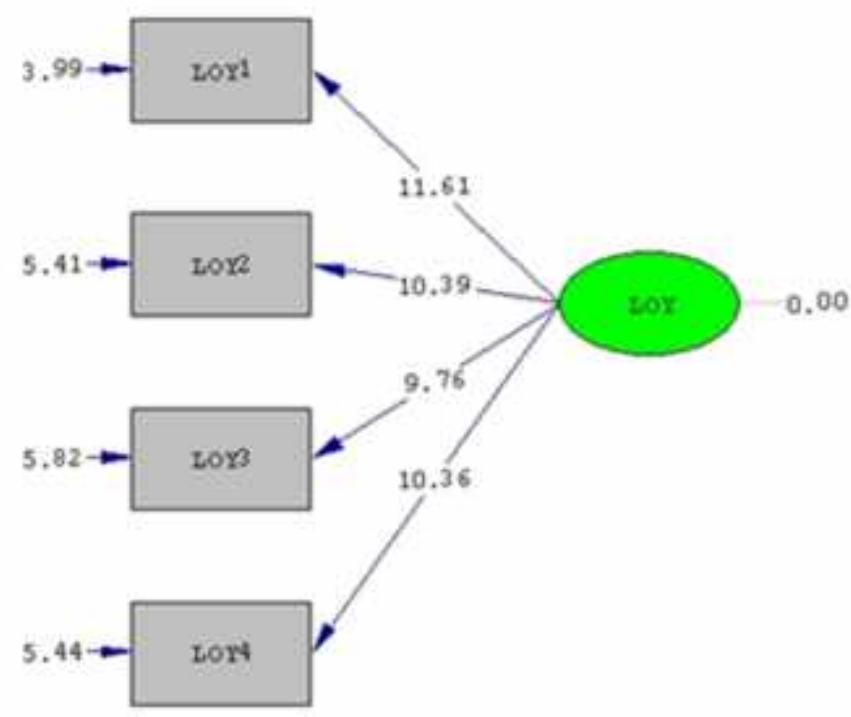

Chi-Square $=0.20$, df $=2$, P-value $=0.90338$, RMSEA $=0.000$

Gambar 6. Variabel Loyalitas (Loy) CR, data diolah , 2015

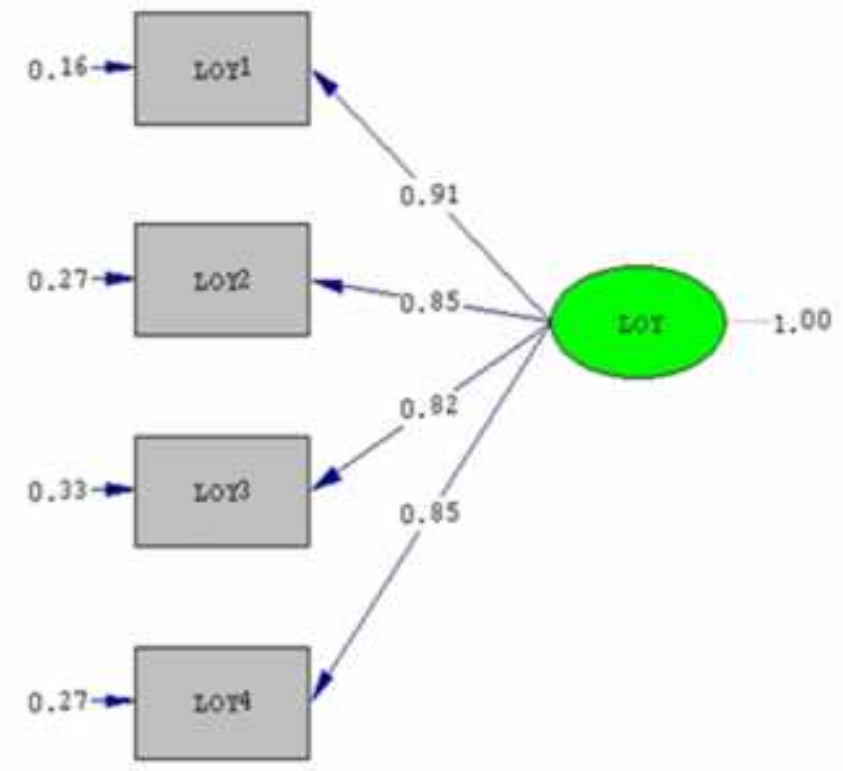

Chi-Square $=0.20, \mathrm{df}=2, \mathrm{P}-\mathrm{value}=0.90338, \mathrm{RMSEA}=0.000$

Gambar 7. Variabel Loyalitas (Loy VE), data diolah , 2015 
Hasil yang diperoleh menunjukkan bahwa seluruh butir pertanyaan yang termasuk dalam variabel Loyalitas signifikans secara statistik. Ini ditunjukkan oleh nilai t-hitung yang diperoleh, di mana seluruh nilai t-hitung yang diperoleh lebih besar dari 1,96.
Nilai CR yang diperoleh sebesar 91.77\% telah memenuhi kriteria, yaitu di atas 0,700 (70\%); dan nilai VE sebesar 73,64\% sudah memenuhi batasan ideal, yaitu diatas 0,500 (50\%); sehingga data yang diperoleh dinyatakan baik.

Tabel 12 nilai Construct Reliability (CR) dan Variance Extracted

\begin{tabular}{|l|l|l|}
\hline Indikator & Loading & Error \\
\hline LOY_1 & 0.91 & 0.17 \\
\hline LOY_2 & 0.85 & 0.28 \\
\hline LOY_3 & 0.82 & 0.33 \\
\hline LOY_4 & 0.85 & 0.28 \\
\hline CR & $91.77 \%$ & \\
\hline VE & $73.64 \%$ & \\
\hline
\end{tabular}

Sumber : Data Peneliti diolah

Sementara itu, tabel di atas menunjukkan nilai loading dari masing - masing indikator untuk Variabel Loyalitas. Dengan nilai tersebut dihitung Construct Reliability (CR) dan Variance Extracted(VE)

\section{STRUCTURAL EQUATION MODELING}

Berdasarkan pada output Analisis SEM yang menggunakan software LISREL 8.8 (Student Version) diperoleh nilai-nilai yang digunakan sebagai acuan dalam pengujian model secara keseluruhan.

Tabel 13 .Uji Kecocokan pada Beberapa Kriteria Goodness of Fit Index

\begin{tabular}{|l|l|l|}
\hline Goodness of Fit Index & Cut Off Value & Hasil Penelitian \\
\hline Derajat bebas (DF) & Positif & 67 \\
\hline P-value & $\geq 0,05$ & 0,083 \\
\hline RMSEA & $\leq 0,08$ & 0,050 \\
\hline GFI & $\geq 0,90$ & 0,89 \\
\hline AGFI & $\geq 0,80$ & 0,83 \\
\hline
\end{tabular}

Sumber : Data Peneliti diolah 
Koefisien Goodness of Fit di atas menunjukkan adanya kecocokan model dengan tingkat kecocokan yang baik. Diperoleh nilai P-Value sebesar 0,083 berada jauh di atas nilai minimal yang disyaratkan yaitu sebesar 0,050; nilai RMSEA yang disyaratkan lebih kecil dari 0,080 diperoleh sebesar 0,05; begitu pula dengan nilai GFI dan AGFI yang berada atau hampir mendekati nilai yang dianjurkan sebesar 0.83. tingkat kecocokan yang baik. Setelah dilakukan pengujian secara keseluruhan, langkah selanjutnya adalah melakukan pengujian secara individual, yaitu untuk melihat apakah seluruh jalur yang dihipotesiskan memiliki tingkat signifikansi yang baik atau tidak. Untuk mengetahui apakah masing-masing jalur memiliki tingkat signifikansi yang tinggi atau tidak dilakukan dengan melihat nilai t-hitung yang diperoleh.

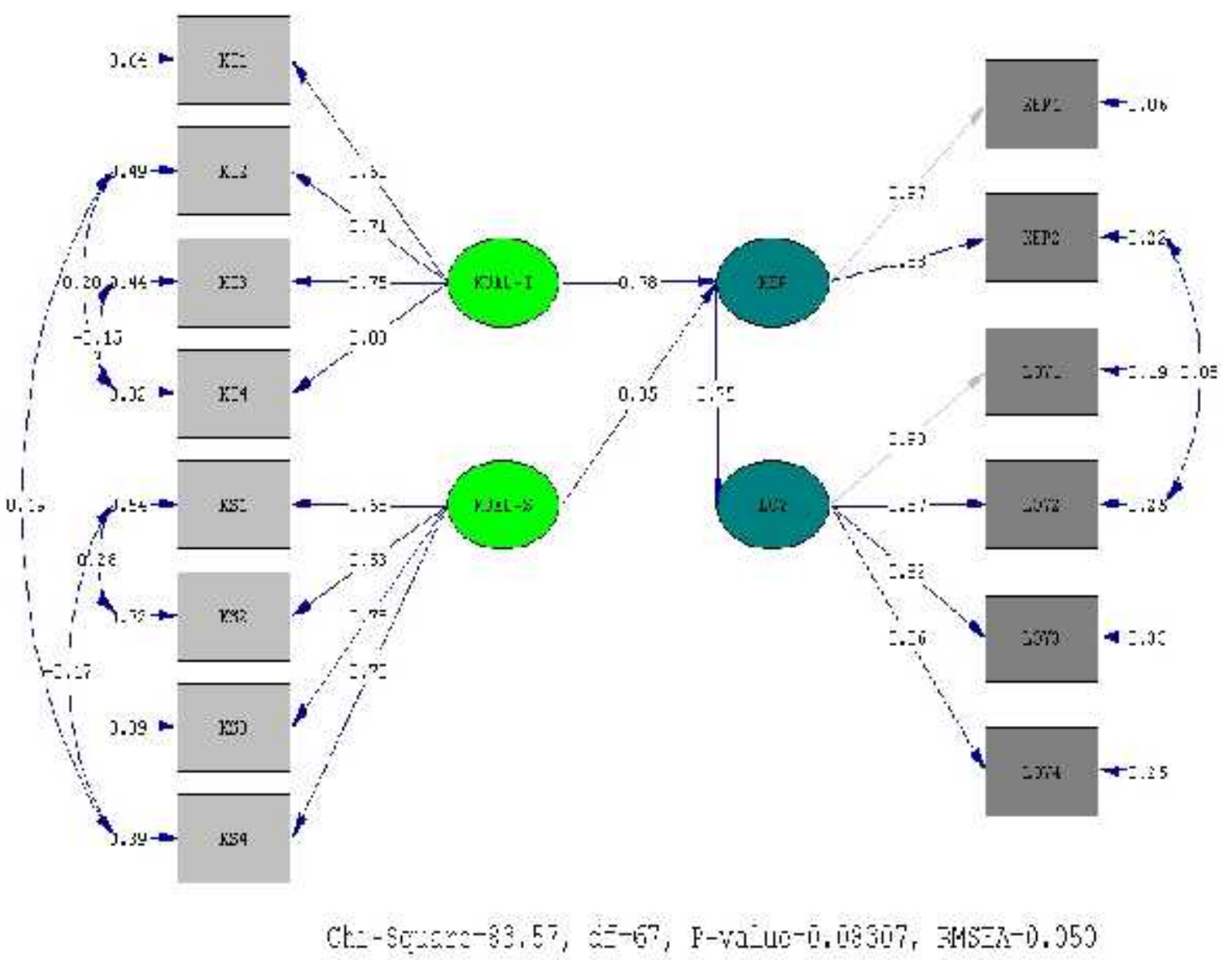

Gambar 8. Pengujian Jalur Individual - Measurement Model data diolah , 2015

Berdasarkan pada nilai-nilai koefisien diatas yang memenuhi persyaratan kecocokan sebuah model, maka dapat disimpulkan bahwa secara umum, model yang diperoleh memiliki
Sebuah jalur dikatakan signifikan jika nilai thitung untuk jalur tersebut lebih besar dari 1,96. Berikut diagram yang berisikan nilai- 
nilai t-value dan Standardized Solution untuk seluruh koefisien jalur : diperoleh yaitu sebesar 9,16, yaitu lebih besar dari 1,96 .

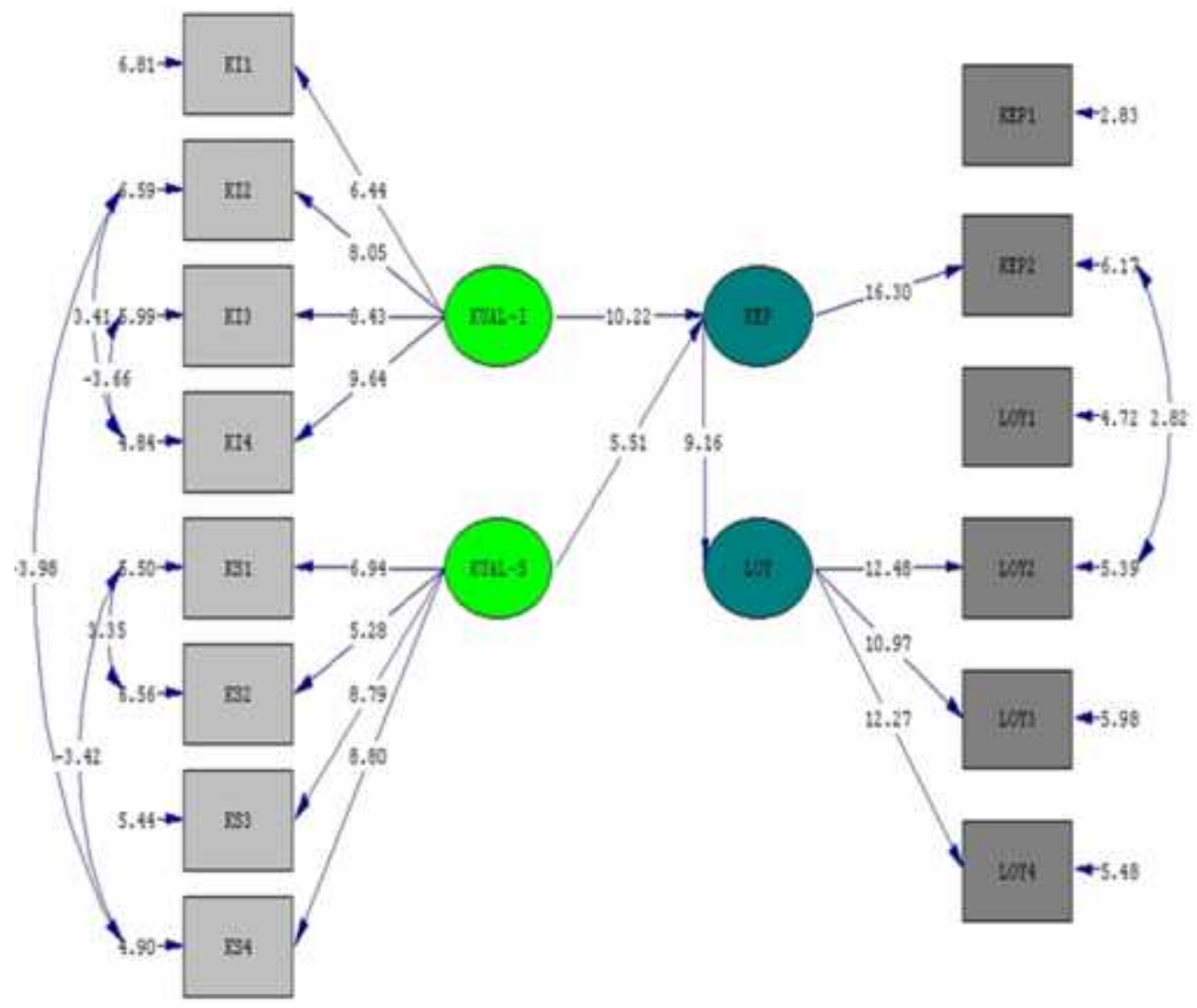

Chi-Square $=83.57, \mathrm{df}=67, \mathrm{P}$-value $=0.08307, \mathrm{RMSEA}=0.050$

Gambar 9. Pengujian Jalur Individual - Measurement Model data diolah , 2015

Dari gambar diatas terlihat bahwa seluruh jalur yang dihipotesiskan memiliki nilai thitung yang lebih besar dari 1,96 dan dapat disimpulkan bahwa seluruh koefisien jalur tersebut signifikan. Terlihat bahwa pada model yang dihipotesiskan, variabel Loyalitas dipengaruhi secara signifikans oleh Variabel Kepuasan. Variabel Kepuasan memberikan pengaruh yang signifikans secara statistik dengan melihat pada nilai t-value yang
Sementara itu, variabel Kepuasan dipengaruhi oleh dua variabel bebas, yaitu Variabel Kualitas Informasi dan Kualitas Sistem. Kedua variabel bebas tersebut memiliki nilai t-hitung sebesar 10,22 dan 5,51. Kedua nilai tersebut lebih besar dari 1,96 sehingga dinyatakan signifikan secara statistik.

Besar pengaruh Variabel Kepuasan terhadap Loyalitas adalah sebesar 0,75 atau $75 \%$; sedangkan pengaruh dari Variabel Kepuasan 
Internal dan Kepuasan Sistem adalah sebesar $78 \%$ dan $35 \%$. Sedangkan pengaruh secara total adalah sebesar $58 \%$.

\section{PENUTUP}

\section{Simpulan}

Uji validitas dan reliabilitas yang dilakukan untuk seluruh dimensi, dari seluruh pertanyaan yang digunakan telah memenuhi persyaratan validitas dan reliabilitas. Dengan melihat nilai CR dan nilai VE yang diperoleh dapat dinyatakan bahwa data yang diperoleh dinyatakan baik.Nilai t-hitung yang diperoleh dari Confirmatory Factor Analysis (CFA) untuk seluruh variabel menunjukkan bahwa seluruh butir pertanyaan yang termasuk dalam seluruh variabel signifikan secara statistik.Nilai koefisien Goodness of Fit memenuhi persyaratan kecocokan sebuah model, maka dapat disimpulkan bahwa secara umum, model yang diperoleh memiliki tingkat kecocokan yang baik.

Kualitas layanan ATM mempunyai hubungan positif signifikan secara statistik dengan loyalitas pelanggan.Kepuasan terhadap kualitas kandungan informasi ATM dan kepuasan terhadap kinerja sistem ATM ternyata memang memiliki hubungan yang positif dengan kepuasan pelanggan. Variabel kepuasan dipengaruhi signifikan secara statistik oleh dua variabel bebas, yaitu Variabel Kualitas Informasi dan Kualitas
Sistem. Kepuasan akan berdampak pada kepercayaan pelanggan terhadap penggunaan ATM sehingga akan muncul loyalitas pelanggan terhadap ATM pada Bank tersebut. Sesuai dengan hipotesa bahwa variabel kepuasan memberikan pengaruh yang signifikan secara statistik terhadap variabel loyalitas.

\section{Saran}

Saran yang dapat diberikan oleh peneliti untuk penelitian dapat menggunakan indikator lain dalam mengukur kepuasan pelanggan dengan faktor mediasi yang lainnya. Bank BUMN sebagai objek dari penelitian berikutnya. Hal tersebut untuk melihat apakah terdapat perbedaan antara kepuasan pelanggan pada Bank Swasta atau Bank BUMN. Sehingga hasilnya bisa digeneralisasi. Ukuran sampel harus diperbanyak agak hasil penelitian lebih baik lagi.Menggunakan sampel dari seluruh wilayah di Indonesia agar hasil penelitian lebih baik lagi. Menggunakan software LISREL yang full versión sehingga penelitian berikutnya dapat menggunakan variabel yang lebih banyak untuk mengukur tingkat kualitas dan kepuasan pengguna terhadap loyalitas pelanggan.

\section{DAFTAR PUSTAKA}

Azwar, Saifuddin. 2000. Reliabilitas dan Validitas. Pustaka Pelajar Clemons. E. K., 1991, Sustaining IT Advantage: The Rule of Structure Differences, MIS Quarterly 15, Vol 3, p 274-292. 
et al., 1992, The Impact of Information Technology on the Organization of Economic Activity: The "Move to the Midie" Hypothesis, Journal of Management Information Systems

Bowen, J. T., and S.L. Chen. 2001. The relationship between customer loyalty and customer satisfaction. International Journal of Contemporary Hospitality Management (May): 213-217.

Doll, Xia, dan Torkzadeh. 1994. A Confirmatory Factor Analysis of The End-User Computing Satisfaction Instrument. MIS Quarterly.

Caruana, Albert. 2002. Service Loyalty \; The Effects of Service Quality and The Mediating Role of Customer Satisfaction. European Journal of Marketing, Vol. 36 No. 7.

Hallowell, R. 1996. The relationships of customer satisfaction, customer loyality, and profitability: an empirical study. International Journal of Service Industry Management 7 (4): 27-42.

Huck. Schuyler W. (2000), Reading Statistics And Research. Third Edition, Addision Wesley Longman. Inc. Jarvenpaa, S.L.

Islam, Dr. Md. Rafiqul., Dr. Samir Kumar Sheel, Pallab Kumar Biswas. 2004. Customer Satisfaction of ATM Service: A Case Study of HSBC ATM.

Jones, T.O., and W. E. Sasser (1995). Why satisfied customers defect. Harvard Business Review (November-December): 88-99

Kandampully, J., and D. Suhartanto (2000). Customer loyalty in the hotel industry: The role of customer satisfaction and image. International Journal of Contemporary Hospitality Management (December): 346-351

Litan, R. E. 1999. ATM Fees: An Economic Analysis. www.aba.com/aba/(acessed on 17.09.05)

Livari, Juhani. 2005. An Empirical Test of The DeLone-McLean Model of Information System Success. Database for Advances in Information Systems.

McKinney, Vicki et al. 2002. The Measurement of Web-Customer Satisfaction: An Expectation and Disconfirmation Approach. Information Systems Research.

Mittal, B., and W.M. Lassar. 1998. Why do customer switch? The dynamic of satisfaction versus loyalty. The Journal of Secrvice Marketing 12 (3): 177-194.

Nunnaly, J. C., dan Ira H. Bernstein.(1994), Psycometric Theory. Third Edition, Mc Graw Hill, Inc., New York.

Oliver, R. L. 1999. Whence consumer loyalty. Journal of Marketing 63: 33-44

Raihan, A., S.R. Khan, M.R. Alam, and K. Rabbi., 2001. Computerization and IT in Banking Sector: Hindrances and Remedies. Bank Parikrama (Dhaka: BIBM), Vol. XXVI No. 1, p. 95-133

Wijanto, Setyo Hari. 2006. Konsep dan Tutorial: Structural Equation Modeling dengan LISREL 8.8 (Handbook). Pasca Sarjana Ilmu Manajemen Fakultas Ekonomi UI. 